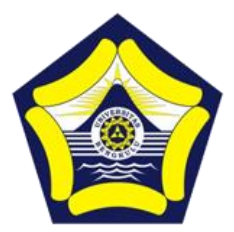

\title{
The Influence of Human Resource Information System (HRIS) Effectiveness on Employees' Performance at Brankas
}

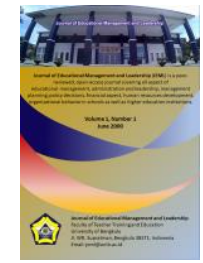

\author{
Ika Nur Afifah ${ }^{1, *}$, Fetty Poerwita Sary ${ }^{2}$ \\ 'International ICT Business, Faculty of Economic and Business, Telkom University \\ ${ }^{2}$ Faculty of Economic and Business, Telkom University \\ *Email: ikanur37@gmail.com
}

DOI: https://doi.org/10.33369/jeml.1.2.61-67

\begin{abstract}
Since the 21 st century, the use of data makes it possible to assist in making decision and business strategies. Human Resource Information System (HRIS) is an excellent example of utilizing savings in administrative costs and also taking strategies that can benefit companies or organizations by gathering information, processing and sharing. The purpose of this research was to understand the influence of HRIS effectiveness on employees' performance at Brankas. The method used in this research was a quantitative method with data collection technique through the distribution of questionnaires. The type of analysis used is descriptive and causal with the data analysis used descriptive analysis, simple linear regression, determination coefficient, and hypothesis testing. The results of this study showed that HRIS has significant influence on employees' performance at Brankas. The results of this study should be used as input for Brankas through developing and improving the system of HRIS to help the company more efficient in terms of time management by the time set up.
\end{abstract}

Keywords: Human resource, employees' performance, human resource information system, effectiveness.

\section{INTRODUCTION}

In today's knowledge-based economy, technology is playing a pivotal role in shaping every area of our life. Khashman (2016) stated that technological innovation in every business function includes a significant influence on the performance of organizations, and it helps to boost the competitiveness of the firms and thus to extend the company's value.The success of organizations depends totally on the performance of human resource management. Besides, Troshani et al., (2011) argues human resource management recently changed concentricity on sharing of information and strategy analysis and it's been increased rapidly evolving to a considerable contributor to the strategic of organizational management.Therefore, to extend the effectiveness of HRM. Organizations and firms have become more captivated with HRIS, explained by Khasman (2016). In addition, Troshani et al., (2011) explained that within the functional level, HRIS can track the employees, applicants and contingent workers in any condition. In addition, it's included demographics, performance appraisal, payroll, professional development, retention, and recruitment. Khashman (2016) explained one of the essential changes has been the trendy use of knowledge Systems in support of HR processFurthermore, companies and organizations nowadays have become more captivated with HRIS to extend the effectiveness of human resource management in line with Khashman (2016).

Sadiq et al (2012) explained that each organizations or companies nowadays considered HRIS as an integralpart of any organization's functions. It is noted that more and more organizations are developing information technology that might help the organization and corporations to realize the 
goals promptly which might help them make more strategic decisions by profiting from the system. In the internet and knowledge era, businesses, on the one hand, work on company efficiency and productivity while on the opposite hand, the company struggles to accomplish a crucial strategic goal like keeping in check employees' performance which keeps it up and uses efficiently.

Besides that, companies or organizations that have used HRIS realize that the employment of HRIS is very important to reinforce human resource management activities. Dewi (2014) explain "The potential benefits of HRIS are information that can be processed faster, more accurately, greater information towards planning, program improvement and development, and improving employee communication".

The effectiveness of HRIS at Brankas to simplify employee's performance using its data that have been provided from the company to make employee's work easier and its process. The higher result of employee's performance will give a positive influence to the company because it will improve efficiency according to Hosnavi and Ramezan(2010).

According to Hasibuan (2012), Human Resource Management (HRM) is the science and art of regulating the relationships and roles of the workforce in realizing corporate, employee, and community goals effectively and efficiently. According to Rivai et al., (2014) reports that, "Human Resource Management (HRM) is one area of general management that includes aspects of planning, organizing, effectiveness, and controlling". Based on the two explanations above, it can be said that to determine, interpret, and achieve company goals, the management of human resources includes planning, organizing, effectiveness, and controlling functions.

Brankas has used an effective HRIS to help the people management division, it makes easier to maintain the employees, besides that, it uses to make the workflow easier for the employees. This system is provided by people management of Brankas to facilitate employee interaction with employment data which include information task or job desk, task given to the employee, recruitment, payroll, and master employee data. In addition, the employees can track the performance by finishing the task and it is written by the system. However, based on the interviewees, described that the employee has difficulty to submit the deadline given on time within the same deadline. The information and system deadline given is very important to determine how effective is the HRIS on employee's performance. Employees' performance is one of the indicators for company to be successful to reach the company's goal. There are many ways for company to facilitate the employees in order to improve the employees' performance, one of them is by implementing HRIS to be effective. Whereas Bastian in Fahmi (2015) states that performance is a description level of achievement of an activity/ program/ policy in realizing the goals, objectives, mission, and vision of the organization contained in the formulation of a strategic plan for an organization. So it can be concluded that performance is the result of the effectiveness of an activity, program, and work in both quality and quantity. According to Bernardin and Russel in Sudarmanto (2015), performance is the record of outcomes produced on a job function or activity during the time of its job.

\section{RESEARCH METHOD}

The method used in this research is the quantitative method. The purpose of this research is to describe the value between two variables used to measure an object. Descriptive research is used in the first statement and the second statement regarding HRIS and employees' performance at Brankas. This research was conducted at Brankas. Brankas is a developing startup in Indonesia.

In this paper, the object of research (population) is all people involved in the process of administering the Information system (HRIS) at Brankas. In 2019 total permanent employees of Brankas 61 according to people management division of Brankas. Thus, the population of this research is all the employees of Brankas.

The technique chosen for this research is a non-probability sampling. The non-probability technique sample will be used as a saturation sample. Saturation sample based on Sujarweni 
(2015:88) is a technique where all the population will be the sample. Therefore, the sample of this research is all the employees of Brankas which mean 61 people.

\section{RESULTS AND DISCUSSION}

\section{Respondents' Respond on HRIS}

This research consists of 38 variables of HRIS as an independent variable $(\mathrm{X})$ used five choices which were strongly disagree (SD), disagree (D), sufficient (S), agree (A), and strongly agree (SA). The result of the response based on questionnaires given to 61 Brankas's employees is shown in Table 1.

Table 1. Respondent's Respond on HRIS

\begin{tabular}{|c|c|c|c|c|c|c|c|c|c|}
\hline Item & SD & D & $\mathbf{S}$ & $\mathbf{A}$ & $\mathbf{S A}$ & Total & Total Score & Percentage $(\%)$ & Ideal Score \\
\hline 1 & 0 & 0 & 2 & 25 & 34 & 61 & 276 & 90.49 & \multirow[t]{37}{*}{305} \\
\hline 2 & 0 & 0 & 2 & 27 & 32 & 61 & 274 & 89.84 & \\
\hline 3 & 0 & 0 & 1 & 32 & 28 & 61 & 271 & 88.85 & \\
\hline 4 & 0 & 0 & 3 & 27 & 31 & 61 & 272 & 89.18 & \\
\hline 5 & 0 & 0 & 2 & 26 & 33 & 61 & 275 & 90.16 & \\
\hline 6 & 0 & 0 & 1 & 24 & 36 & 61 & 276 & 90.49 & \\
\hline 7 & 0 & 0 & 1 & 24 & 36 & 61 & 276 & 90.49 & \\
\hline 8 & 2 & 33 & 17 & 4 & 5 & 61 & 160 & 52.46 & \\
\hline 9 & 3 & 30 & 20 & 8 & 0 & 61 & 155 & 50.82 & \\
\hline 10 & 0 & 0 & 5 & 34 & 22 & 61 & 261 & 85.57 & \\
\hline 11 & 0 & 0 & 2 & 39 & 20 & 61 & 262 & 85.90 & \\
\hline 12 & 0 & 0 & 3 & 28 & 30 & 61 & 271 & 88.85 & \\
\hline 13 & 0 & 0 & 3 & 30 & 28 & 61 & 269 & 88.20 & \\
\hline 14 & 0 & 0 & 4 & 25 & 32 & 61 & 272 & 89.18 & \\
\hline 15 & 0 & 0 & 5 & 25 & 31 & 61 & 270 & 88.52 & \\
\hline 16 & 0 & 0 & 0 & 33 & 28 & 61 & 272 & 89.18 & \\
\hline 17 & 0 & 0 & 1 & 25 & 35 & 61 & 278 & 91.15 & \\
\hline 18 & 0 & 0 & 1 & 32 & 28 & 61 & 271 & 88.85 & \\
\hline 19 & 0 & 0 & 1 & 28 & 32 & 61 & 275 & 90.16 & \\
\hline 20 & 0 & 0 & 1 & 30 & 30 & 61 & 273 & 89.51 & \\
\hline 21 & 0 & 0 & 1 & 29 & 31 & 61 & 274 & 89.84 & \\
\hline 22 & 0 & 0 & 1 & 31 & 29 & 61 & 272 & 89.18 & \\
\hline 23 & 0 & 0 & 2 & 30 & 29 & 61 & 271 & 88.85 & \\
\hline 24 & 0 & 0 & 4 & 26 & 31 & 61 & 271 & 88.85 & \\
\hline 25 & 0 & 0 & 3 & 29 & 29 & 61 & 270 & 88.52 & \\
\hline 26 & 0 & 0 & 2 & 32 & 27 & 61 & 269 & 88.20 & \\
\hline 27 & 0 & 0 & 2 & 31 & 28 & 61 & 270 & 88.52 & \\
\hline 28 & 0 & 0 & 3 & 31 & 27 & 61 & 268 & 87.87 & \\
\hline 29 & 0 & 0 & 2 & 30 & 29 & 61 & 271 & 88.85 & \\
\hline 30 & 0 & 0 & 1 & 28 & 32 & 61 & 275 & 90.16 & \\
\hline 31 & 0 & 0 & 1 & 34 & 26 & 61 & 269 & 88.20 & \\
\hline 32 & 0 & 0 & 1 & 26 & 34 & 61 & 277 & 90.82 & \\
\hline 33 & 0 & 0 & 2 & 31 & 28 & 61 & 270 & 88.52 & \\
\hline 34 & 0 & 0 & 1 & 29 & 31 & 61 & 274 & 89.84 & \\
\hline 35 & 0 & 0 & 1 & 36 & 24 & 61 & 267 & 87.54 & \\
\hline 36 & 0 & 0 & 2 & 27 & 32 & 61 & 274 & 89.84 & \\
\hline 37 & 0 & 0 & 1 & 28 & 32 & 61 & 275 & 90.16 & \\
\hline
\end{tabular}




\begin{tabular}{|l|l|l|l|l|l|l|l|l|l|}
\hline 38 & 0 & & 1 & 32 & 28 & 61 & 271 & 88.85 & \\
\hline \multicolumn{6}{|c|}{ Total score } & 10097 & 87.11 & \\
\hline
\end{tabular}

Based on Table 1 described the result of the respondent's responseto HRIS had three dimensions which were information quality, system quality, and system usage. Information quality had fifteen item questions and on the first, sixth and seventh item had the highest score which was 90.49\% and those items had the same percentage and it described that employee satisfied with an accusation of its information on the first item, comprehension of the information on the sixth item and completeness of the information on the seventh item which given by Brankas. However, the ninth item had the lowest score which is $50.82 \%$ and it described that employee disagrees on the ninth item regarding support the submit on time by the system because the system based in Singapore meanwhile, most of the employees working remotely and could not submit the task on time because of the different time zone.

The second dimension was about system quality which had tenth item questions and the highest score was on the seventeenth item $91.15 \%$ justified that the employee agree on the system can be accessed only by the employee and the lowest score is on the twenty-fifth item $88.52 \%$ it shows that the employee agree on HRIS have a system to save information when there was an interruption.

The third dimension was about system usage which has thirteenth item questions and the highest score was thirty-two item $90,82 \%$, it means the employee agrees on by using HRIS was more efficient to report to any activities. Meanwhile, the lowest score was on twenty-sixth item $88.20 \%$ it means the employee also agree using HRIS, employees able to track the performance of achievement via HRIS.

Overall based on the questionnaires result on HRIS, the final the percentage result was $87.11 \%$ with total score of 10097 . The final result of percentage based on the continuum will be on very high. Below,the continuum line which interpreted based on the final score percentage on HRIS:

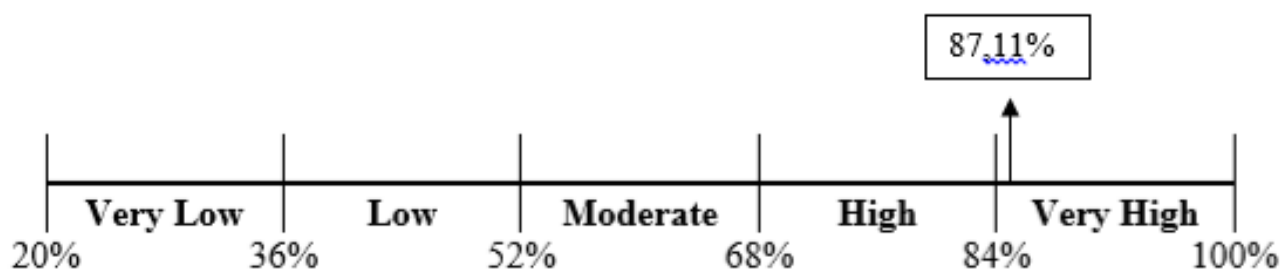

Figure 1. Continuum Line Interpreted by HRIS's Final Score

Based on figure 1 described that HRIS variable was very high and it means the HRIS system given by Brankas to facilitate and support the employees wasvery likely based on the expectation of its employees. The HRIS at Brankas has problem with time management such as could not able to submit the task on time or capable to provide the information on time so the employee more likely disagrees to answer the items and it influence the score on HRIS variable.

\section{Respondents' Respond to Employees' Performance}

This research consist of 14 variables of Employees' Performance as dependent variable (Y) used five choices which werestrongly disagree (SD), disagree (D), sufficient (S), agree (A), and strongly agree (SA). The result of the response based on questionnaires given to 61 Brankas's employees is summarized in Table 2. Based on Table 2 described the result of the respondent's respond to employee performance and it has six variables. The first dimension wasabout quality and it has two questions which the first item has the highest score 93,11\% because the employees understand the data and information that had been delivered and the data was clear to understand. 
The second question has the lowest score $88.85 \%$ described that the employees can solve problems in managing data accurately.

Table 2. Respondent's Respond on Employees' Performance

\begin{tabular}{|c|c|c|c|c|c|c|c|c|c|}
\hline Item & SD & D & $\mathbf{S}$ & $\mathbf{A}$ & SA & Total & Total Score & Percentage $(\%)$ & Ideal Score \\
\hline 1 & 0 & 0 & 1 & 19 & 41 & 61 & 284 & 93.11 & \multirow[t]{14}{*}{305} \\
\hline 2 & 0 & 0 & 2 & 27 & 32 & 61 & 271 & 88.85 & \\
\hline 3 & 0 & 0 & 4 & 29 & 28 & 61 & 259 & 84.92 & \\
\hline 4 & 0 & 0 & 4 & 32 & 25 & 61 & 256 & 83.93 & \\
\hline 5 & 2 & 34 & 18 & 7 & 0 & 61 & 152 & 49.84 & \\
\hline 6 & 0 & 0 & 5 & 35 & 21 & 61 & 248 & 81.31 & \\
\hline 7 & 0 & 3 & 8 & 27 & 23 & 61 & 226 & 74.10 & \\
\hline 8 & 0 & 0 & 5 & 28 & 28 & 61 & 255 & 83.61 & \\
\hline 9 & 0 & 0 & 6 & 29 & 26 & 61 & 249 & 81.64 & \\
\hline 10 & 0 & 0 & 4 & 26 & 31 & 61 & 262 & 85.90 & \\
\hline 11 & 0 & 0 & 2 & 30 & 29 & 61 & 268 & 87.87 & \\
\hline 12 & 0 & 0 & 2 & 31 & 28 & 61 & 267 & 87.54 & \\
\hline 13 & 0 & 0 & 9 & 24 & 28 & 61 & 239 & 78.36 & \\
\hline 14 & 0 & 0 & 12 & 24 & 25 & 61 & 224 & 73.44 & \\
\hline \multicolumn{7}{|c|}{ Total score } & 3460 & 81.03 & \\
\hline
\end{tabular}

The second dimension was about quantity and it has two questions. The third item has the highest score $84,93 \%$ described that the employees felt the system helped the employees to reach the target based on the company's required. The fourth item has the lowest score $83.93 \%$ described that the employees felt the system helped to minimize the mistake.

The third dimension is about timeliness and it has three questions. The highest score is on the sixth item $81.31 \%$ described the employees felts it was easier to record the attendance by using the system. Meanwhile, the lowest score was on the fifth item $49.84 \%$ regarding the system helped the employees to deliver the job on time. Justified that the employees could not submit the task on time.

The fourth dimension was about cost-effectiveness and it has three questions. The highest score was on eighth item $83.61 \%$ described about the employees felt that the system facilitates employees' career. The lowest score is on the seventh item $74.10 \%$ described that the employees felts the schedule given by the company is sufficient to do the task or to complete the tasks given by the company.

The fifth dimension is about the need for a supervisor and it has two questions. The highest score based on the eleventh item $87.87 \%$ described that the employees felt the manager is very responsive when there is an error or problem that happened. Furthermore, the lowest score was on the twelfth item $87.54 \%$ about the manager supervises the employees for the job the employees did.

The sixth dimension was about the interpersonal impact and it has two questions. The highest score on the thirteenth item $78.36 \%$ regarding how the employees felt about the system helped to communicate with the co-workers. The lowest score is on the fourteenth item $73.44 \%$ regarding the system helped to improve teamwork capability. Some employees thought the system needs to be improved to improve teamwork also communication.

Based on those fourteenth questions on employees' performance variables described that the final percentage was $81.03 \%$ with total score of 3460 . The final result will be interpreted on a continuum line and it will be on a high level. Below, the continuum line on employees' performance variable: 


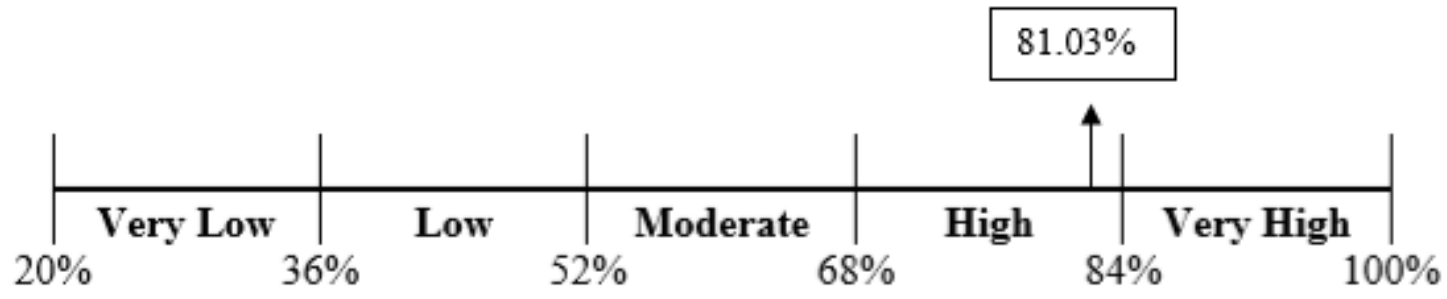

Figure 2. Continuum Line Interpreted by Employees’ Performance Final Score

Based on Figure 2 described that the employees' performance on Brankas was high or good. The employees felt the quality works was good and based on standard also the quantity given by the company was sufficient. Regarding timeliness, it was a bit tricky because some of the employees could not able to meet the deadline. The employees felt that the manager or team leader helped whenever there was a problem. Aside from that, the employees also tried to keep the teamwork good the communication to support each other.

\section{Simple Linear Regression}

The result of simple linear regression analysis which author have been measured using SPSS 25 version as follow:

Table 3. Simple Linear Regression Analysis.

\begin{tabular}{|c|c|c|c|c|c|}
\hline \multirow{2}{*}{ Model } & \multicolumn{2}{|c|}{$\begin{array}{c}\text { Unstandardized } \\
\text { Coefficients }\end{array}$} & $\begin{array}{c}\text { Standardized } \\
\text { Coefficients }\end{array}$ & $\mathrm{t}$ & Sig. \\
\cline { 2 - 6 } & $\mathrm{B}$ & Std. Error & Beta & & \\
\hline \multirow{2}{*}{$\begin{array}{c}\text { (Constant) } \\
\text { HRIS }\end{array}$} & 8.370 & 7.236 & & 1.157 & .252 \\
\cline { 2 - 6 } & .308 & .044 & .677 & 7.067 & .000 \\
\hline
\end{tabular}

a. Dependent variable: Employees' performance

Based on the results of simple linear regression analysis, the simple linear regression equation obtained:

$$
\mathrm{Y}^{\prime}=8.370+0.308 \mathrm{X}
$$

Described that the constant value obtained is 8,370 meaning that if the value of the independent variable HRIS was zero (0), then the value of the dependent employees' performance variable was 8.370. The regression coefficient value was 0.308 meaning that if there was an increase in HRIS 1 unit, it will increase employees' performance by 0.308 unit.

\section{Coefficient of Determination}

The result of coefficient of determination which author have been measured using SPSS 25 version as follow:

Table 4. The Result of Coefficient of Determination Model Summary

\begin{tabular}{|c|c|c|c|c|}
\hline Model & R & R Square & Adjusted R Square & Std. Error of the Estimated \\
\hline 1 & $.677 \mathrm{a}$ & .458 & .449 & 4.738 \\
\hline
\end{tabular}

a. Predictors: (Constant), HRIS

Based on the table above we got the value of R Square or the coefficient of determination (Cd) which showed how good the regression model formed by the interaction of independent variables and dependent variables.

$$
\mathrm{Cd}=0.677^{2} \times 100 \%=45.8 \%
$$


Cd value obtained was $45.8 \%$ which can be interpreted that the independent variable $\mathrm{X}$ hada contribution of $45.8 \%$ to the variable $\mathrm{Y}$ and another $54.2 \%$ was influenced by other factors outside the $\mathrm{X}$ variable.

\section{CONCLUSIONS}

Based on research results that have been discussed above, it can be concluded that,

1. The system of HRIS provided by Brankas to employees categorized in a very high category justified by $87.11 \%$ in percentage. Which means based on continuum line interpreted that the level of the effectiveness HRIS provided by the company was very high and the employees feel that the HRIS given by the company was in line with employee expectations.

2. The employees' performance of Brankas categorized in a high category with a percentage of $81.03 \%$. Which means based on the continuum line, it showed that the level of employees' performance was high and it means the employee has performance was good at carrying out the work.

3. Hypothesis testing results indicate $\mathrm{H} 1$ was accepted and the results of simple linear regression analysis showed positive results meaning that the effectiveness of HRIS had a positive and significant effect on employees' performance of Brankas. The results of the coefficient of determination obtained indicate that the effectiveness of HRIS has a $45.8 \%$ effect on employees' performance, meanwhile the rest of the percentage which is $54.2 \%$ influenced by other variables that are not explained in this research.

\section{REFERENCES}

Dewi, Irra Chrisyanti. (2014). Sistem Informasi Sumber Daya Manusia (Cetakan Pertama). Jakarta: Prestasi Pustakaraya.

Fahmi, Irham. (2015). Managemen Kinerja Teori dan Aplikasi. Alfabeta, 4

Hasibuan, Drs. H. Malayu S.P. (2012). Manajemen Sumber Daya Manusia (Cetakan keenam belas). Jakarta: PT. Bumu Aksara.

Hosnavi, R., \& Ramezan, M. (2010). Measuring the effectiveness of Human Resource Information System in National Iranian Oil Company. Education, Business and Society, 3(1), 28-39. Doi:10.1108/17537981011022797.

Khashman, I. M., \& Khashman, A. M. (2016). The Impact of Human Resource Information System (HRIS) Applications on Organizational Performance (Efficiency and Effectiveness) in Jordanian Private Hospitals. Journal of Management Research, 8(3), 31. doi:10.5296/jmr.v8i3.9419

Rivai, V. (2009). Manajemen Sumber Daya Manusia untuk Perusahaan: dari Teori ke Praktik. Jakarta: RajaGrafindo Persada

Sadiq, U., Khan, A. F., Ikhlaq, K., \& Mujtaba, B. G. (2012). The Impact of Information Systems on the Performance of Human Resources Department. Journal of Business Studies Quarterly, 3, 2152-1034, 77-91. Retrieved February 19, 2019.

Sujarweni, W. (2015). Metodologi Penelitian Bisnis \& Ekonomi (Cetakan pertama). Yogyakarta: Pustaka Baru Press.

Sudarmanto. (2015). Kinerja dan Pengembangan Kompetensi SDM: Teori, Dimensi, Pengukuran, dan implementasi dalam Organisasi. Yogyakarta: Pustaka Pelajar.

Troshani, I., Jerram, C., \& Rao, S. (2011). Exploring the public sector adoption of HRIS. Industrial Management and Data Systems, 111(3), 470-488. 